\title{
Editorial
}

\section{The Challenges of Countering Politicization of Trade Relations and Revitalizing the Multilateral Rule-Based System}

\author{
Giorgio Sacerdoti | ORCID: 0000-0003-2206-8914 \\ Department of Legal Studies, Bocconi University, Milan, Italy \\ giorgio.sacerdoti@unibocconi.it
}

\section{Introduction}

In recent years one of the basic tenets of the multilateral trading system established after WWII by the General Agreement on Tariffs and Trade (GATT) in 1947, confirmed and reinforced by the World Trade Organization (WTO) in 1995, has been threatened by unilateral actions of several of the main State actors, a sign of mounting geopolitical tensions in a multipolar world. That tenet was the 'depoliticization' of trade relations (and, similarly, of investments) in the interest of the development of international trade based on cooperation, nondiscrimination, reduction of border barriers, fair competition, and consumers' benefits, with the ultimate aim to reinforce friendly relations beyond borders.

This liberal approach does not exclude the recognition in the GATT/ WTO system of grounds for unilateral control of trade flows in the interest of economic and non-economic national interests, such as through safeguard measures and recourse to exceptions under Article XX GATT for the protection of non-trade values (morality, human health, environment, exhaustible resources), or in case of international emergencies (Article XXI GATT). Recourse to those actions and countermeasures are, however, in case of abuse subject to impartial rule-based evaluation by the WTO dispute settlement system. 
Recently, we have witnessed instead a host of unilateral restrictive measures justified by political ends, or by countries aiming at protecting national industries well beyond the GATT rules. This has destabilized multi-country supply chains and hampered international economic cooperation. Affected countries have in turn reacted with countermeasures in the form of further restrictions. Basic positive aspects of globalization and multilateralism have been under attack, possibly beyond the intent of the individual actors involved.

An increased attention by States to domestic needs is unavoidable and should not be opposed per se nor labeled protectionism or the poisoned fruit of populism. Attention to protecting employment, ensuring national control of the economy through industrial policies, preserving local manufacturing capability (such as in facing pandemics, a situation that has made this tendency more evident) incapsulates, in any case, the current mood towards deglobalization.

Respect for the individual right of each country to organize its political and economic national system does not require, however, disregarding existing obligations and commitments and brushing away the broader imperative of international cooperation in an interdependent world, lest long-term economic ties, beneficial for all, be seriously disrupted. This is exactly what has happened since 2018.

The Current Crisis of the Multilateral Trading System and the Politicization of Trade Relations

The WTO system has been under strain in recent years because of the inability of members (a) to resolve friction over the application of existing procedural rules (notifications, transparency, dispute settlement, plurilateral agreements) and substantive disciplines, which is due also to diverging views on the adequacy of some of them, such as to subsidies and the role of State-owned enterprises (SOEs); and (b) to negotiate new agreements concerning matters that the existing rule-book, dating back to the mid-199os, does not cover (fisheries, e-commerce, data transfer, services).

This situation has led to, and is evidenced by, the lack of success (and, preliminarily, of engagement) in resolving both types of issues within the WTO. Several G-2o members have pursued other approaches to tackle what they have perceived as their priorities concerning trade. These approaches include unilateralism through protective measures of domestic markets (industries and workers), bilateral deals, (mega) regional agreements and exploring the avenue of plurilateral agreements. 
These developments have been influenced by, and are a sign of, the recent new tendency towards the 'politicization' of trade relations in two respects. First, political interference with trade flows, which are traditionally determined by business choices based on market and competition conditions, derives, indirectly, from the launching of industrial policy programs by several economies ('Made in China 2025', but also the European Union and the United States). These economies include some in which the role of the State has previously been that of a regulator rather than an actor in the market. Such policies aim at actively supporting specific domestic industrial sectors, building capabilities in 'strategic sectors', reshoring production, granting domestic producers preferential access to government procurement, and ensuring domestic ownership and control by screening acquisitions from abroad in broadly understood 'strategic sectors.'

The second recent development is the increased recourse to trade restrictive measures based on political decisions directly interfering with international trade flows at the cost of disregarding international commitments. The multilateral rule-based trade system was inspired, among others, by the aim to somehow isolate the trade regime from the vagaries of political decisions, relations, and disputes by and between WTO members. Except in the case of United Nations Security Council (UNSC) sanctions in connection with international conflicts, trade in products with a military use (dual use), or serious domestic crises, GATT parties and thereafter WTO members have tended to refrain from measures affecting normal trade flows, even in respect of countries with which they do not have particularly friendly relations. This has changed recently. Recourse to export restrictions or discriminatory measures for a variety of reasons have increased. They have been addressed not only against specific countries, but also against specific companies, both by supply/export prohibition and by restricting the use of foreign products by domestic companies (such as in respect of Huawei and ${ }_{5} \mathrm{G}$ telecommunication technology).

These politically motivated measures have been magnified by export restrictions introduced within the COVID-19 pandemic, especially in the form of export restrictions of sanitary devices, and more recently, of vaccines, in order to protect domestic availability. Unilateral restrictions of this type have led to similar counter-restrictions, often frustrating the aims pursued by the countries enacting them. ${ }^{2}$

1 See the Regulation (EU) 2019/452 of 19 March 2019 Establishing a Framework for the Screening of Foreign Direct Investments into the Union (adopted 23 March 2019) L 79 I/1.

2 See the review of these measures in WTO, 'COVID-19: Measures Affecting Trade in Goods' (updated as of 1 February 2021) <www.wto.org/english/tratop_e/covid19_e/trade_related 
The broad tendency to politicization highlighted above may be considered a sign of 'deglobalization', that is subordinating the liberalization of trade to domestic non-trade concerns and objectives. ${ }^{3}$ As part of this development, one can consider the approach followed in recent bilateral and regional free trade agreements (FTAs) (notably by the United States in the United States-Mexico-Canada Agreement (USMCA) and by the European Union) to condition market opening commitments to compliance with non-trade requirements, such as labor and environmental standards.

One cannot criticize the fact that governments prioritize, more than in the past, the welfare of their citizens, or the respect of internationally accepted standards, as compared to the liberalization of trade. If these policies are, however, pursued disregarding existing commitments, the benefits of a predictable and stable framework for beneficial reciprocal trade gets lost. The trading system becomes more fragmented and litigious, a development which the WTO, as a member-driven organization, has difficulty in handling, especially in view of the current semi-paralysis of the dispute settlement system (DSS). The DSS is meant to handle 'normal' disputes stemming from different bona fide interpretations of existing obligations and is based on the willingness of WTO members to voluntarily comply with the decisions. It is not capable of handling political conflicts that directly challenge existing rules.

\section{Recent Developments}

This slippery slope was initiated in 2018 by the imposition by the United States of extra duties on steel and aluminum products beyond the US bound tariffs. The Trump Administration based this action domestically on Section 212 of the Trade Act, dating back to the Cuban Missile Crisis of 1962 and rarely invoked since, while publicly defending the restrictions as an instrument to protect the US domestic industry from foreign competition. Internationally, the United States has relied on the essential security interest exception of Article XXI GATT. This is a provision which the parties had wisely kept dormant for

_goods_measure_e.htm> accessed 28 April 2021. For a critical view, see Richard Baldwin and Simon Evenett (eds), COVID-19 and Trade Policy: Why Turning Inward Won't Work (CEPR Press 202O). For further developments, see 'EU Threat to Vaccine Exports Exposes Mutual Risks to Global Supply Chain' (Financial Times, 18 March 2021).

3 As to the WTO-legality of those restrictions (that might be admissible under Article XI.2, XX (a) and (b) of GATT), see Siddharth S Aatreya, 'Are COVID-19 Related Trade Restrictions WTO-Consistent?' (EJIL:Talk!, 25 April 2020); Caroline Glöcke, 'Export Restrictions Under Scrutiny - The Legal Dimensions of Export Restrictions on Personal Protective Equipment' (EJIL:Talk!, 7 April 2020). 
decades and which had never been subject to panel proceedings before 2017. ${ }^{4}$ In fact, the Trump Administration thereafter started domestic investigations on the automotive industry, threatening to apply Section 212 to car imports from Europe. ${ }^{5}$ What followed were countermeasures in 'self-defense' by most countries hit by extra duties, which also have a dubious foundation in the WTO system, since they had not been authorized by the Dispute Settlement Body (DSB) pursuant to findings of a panel or the Appellate Body. ${ }^{6}$ Measures and countermeasures ended up at the WTO dispute settlement system even though no panel report had yet been issued. ${ }^{7}$

The 'trade war' with China followed with two waves of extra-duties imposed on most imports from China into the United States, a measure for which a GATT basis was not even invoked, not to mention the disrespect for the requirement to go first to dispute settlement proceedings under Article 23 of the Dispute Settlement Understanding (DSU). Further politically motivated trade restrictions have followed, such as by the United States against Hong-Kong, ${ }^{8}$ or between China and Australia. ${ }^{9}$ New export restriction by China on rare earth and critical materials are looming as political measures, while the previous

4 See WTO, Russia-Measures Concerning Traffic in Transit, Report of the Panel (26 April 2019) $\mathrm{WT} / \mathrm{DS}_{512}$.

5 The claim that car imports from the European Union (such as Mercedes or Audi models) could threaten essential security interests of the United States has been defined as ludicrous.

6 See Joseph Weiler, 'Black Lies, White Lies and Some Uncomfortable Truths in and of the International Trading System' (EJIL:Talk!, 25 July 2018).

7 See the cases brought separately by China, India, the European Union, Canada, Mexico, Norway, Russia, Switzerland, and Turkey against the United States in 2018-2019 (WT/DS 544, $547,548,550,551,55^{2}, 554,55^{6}$ and 564 , respectively). Some of these WTO members have adopted immediate trade restrictions against the United States as countermeasures under art 8 of the Safeguards Agreement, having considered the US measures to be in reality disguised safeguards. The United States has in turn challenged these countermeasures as unjustified, claiming that its own measures are bona fide security-based, and started proceedings against Canada, China, the European Union, Mexico, and Turkey (WT/DS 557, 558, 559, 560 and 561 respectively). Since the US measures against Mexico and Canada have been lifted after the conclusion of the USMCA Agreement replacing NAFTA effective 1 July 2020, these cases have been withdrawn. All other cases were pending before panels in mid-2021 with no report issued yet. A mutual lifting of these reciprocal measures as between the United States and the European Union has been envisaged (May 2021)

8 See the statement made by the United States at a meeting of the DSB on 22 February 2021 regarding United States - OriginMarking Requirement, DS $597<$ www.wto.org/english/news_e/ news21_e/dsb_22feb21_e.htm> accessed 28 April 2021. Sun Yu and Demetri Sevastopulo, 'China Targets Rare Earth Export Curbs to Hobble US Defence Industry' (Financial Times, 16 February 2021).

9 See 'China Trade Row Has Cost Australia \$3 Billion in Lost Exports' (Bloomberg News, 21 January 2021) <www.bloomberg.com/news/articles/2021-01-21/china-trade-row-has-cost -australia-3-billion-in-lost-exports> accessed 29 April 2021. 
restrictions had been subject to panel and appellate proceedings at the WTO and rulings, to which China had complied. ${ }^{10}$

In the context of some of the above-mentioned disputes, multilateral rules have been the object of further unauthorized derogations. The European Union has complained that the so-called 'Phase 1' agreement between the United States and China of January 2020, by which some, but not all, of US extra duties were removed (but none of China) was in breach of most-favored nation (MFN) treatment." Only Canada and Mexico have been exempted, thanks to the signing of the USMCA agreement replacing NAFTA in 2020, from the US extra-duties on steel and aluminum, while Brazil and Argentina introduced 'voluntary' export quotas on their exports to the United States.

The challenge to the multilateral rule-based system has also affected, as is well known, its dispute settlement system. The WTO adjudicatory branch has been paralyzed by the US blocking of the Appellate Body by preventing the appointment of its members since 2018. This move can also be labelled as political, since it finds no basis in the WTO agreements as a legitimate reaction by a dissatisfied member in respect of the functioning of the system or its jurisprudence.

Effective and prompt redress of the actions decried above has been made impossible, thus giving an advantage to the strongest party in respect of a weaker party, which may be compelled to concede on the negotiation table advantages that would be legally unwarranted. ${ }^{2}$ From once being rule-based,

10 See Sun Yu and Sevastopulo (n 8).

11 In the so-called 'phase-1' agreement between the United States and China of 15 January 2020, the extra tariffs imposed by the United States on Chinese exports to the United States in 2018 were not lifted (but just reduced in part), leaving the tariffs imposed as countermeasures by China on imports from the United States untouched. See US-China Economic and Trade Agreement (15 January 2020) <https://ustr.gov/sites/default/files/ files/agreements/phase\%2oone\%2oagreement/Economic_And_Trade_Agreement_Bet ween_The_United_States_And_China_Text.pdf > accessed 28 April 2021. The European Union has immediately expressed its objections as to the WTO-consistency of such a bilateral 'mercantilistic' deal, see James Politi, 'EU Trade Commissioner Criticises US-China Trade Deal' (Financial Times, 17 January 2020). China has challenged the US measures at the WTO, while the United States has not impugned China's countermeasures. The Panel in United States - Tariff Measures on Certain Goods from China, WT/DS543, circulated on 15 September 2020, appealed by the United States, has affirmed its jurisdiction notwithstanding the agreement of 15 January 2020 and has found the US measures in breach of GATT arts I and II.

12 All panel reports issued in 2020 (as well as those issued in the first part of 2021) have been appealed 'into the void' to a non-existing Appellate Body. The cases involved are Indonesia - Chicken (WT/DS484) (Article 21.5), EU - Cost Adjustment Methodologies and Anti-Dumping Measures (WT/DS494) (Second Complaint), US - Countervailing 
the trading system is going back to a power-based system. ${ }^{13}$ Further, in respect of dispute settlement, non-compliance calls for non-compliance as a reaction. Thus, the European Union envisages now to immediately adopt countermeasures against the other party of a dispute involving the European Union if the former appeals an unfavorable panel report into the void, i.e. to a non-existing Appellate Body, thus preventing the issuance of a final binding report according to the rules. ${ }^{14} \mathrm{In}$ its most recent policy paper, the Commission proposes to be more assertive in defending its rights and enforcing the deals made with other countries. ${ }^{15}$

The WTO dispute settlement system, as possibly any such system, is not meant to cope with widespread intentional disregard of the substantive rules by the members. Such a system is geared towards solving disputes brought in good faith involving a contentious interpretation or application of specific rules and obligations. A crisis of the institution is inevitable if the number of disputes increase massively, are highly politicized, and the parties drag their feet in complying, when they do not refuse to comply at all. ${ }^{16}$

Measures on Lumber (WT/DS533), US - Tariff Measures on Chinese Goods (WT/DS543), Korea - Sunset Review on Stainless Steel Bars (WT/DS553) (appeal filed on 22 January 2021) and Saudi Arabia - Intellectual Property Rights (WT/567). In Australia - Anti-Dumping Measures on A4 Copy Paper (WT/DS529), the panel report issued on 4 December 2019, was adopted by the DSB on 27 January 2020 .

13 None of the appellants (including of course the United States) have subscribed to the EU initiative establishing a temporary alternative appellate arbitration, see EU Press Release, 'Council Approves a Multi-Party Interim Appeal Arbitration Arrangement to Solve Trade Disputes' (15 April 2020) < www.consilium.europa.eu/en/press/press-releases/2020/04/15/ council-approves-a-multi-party-interim-appeal-arbitration-arrangement-to-solve-trade -disputes/> accessed 28 April 2021. On 31 July 2020, the participants notified the WTO of the ten arbitrators who will hear appeals of WTO panel reports under the multi-party interim appeal arrangement (MPIA), marking the final step to make the MPIA operational for disputes between participants.

14 The European Union has announced that in such a case by an opposing party in a dispute with the European Union, it would resort immediately to countermeasures, relying on general international law principles in the area of State responsibility, see Commission Press Release, 'Commission Reinforces Tools to Ensure Europe's Interests in International Trade' (12 December 2019) <https://trade.ec.europa.eu/doclib/press/ index.cfm?id=2091\&title=Commission-reinforces-tools-to-ensure-Europes-interests -in-international-trade $>$ accessed 28 April 2021. Regulation (EU) 2021/167 Amending Regulation (EU) No 654/2014 Concerning the Exercise of the Union's Rights for the Application and Enforcement of International Trade Rules (in force 12 February 2021) L $49 / 1$.

15 See Commission's Communication, 'Trade Policy Review - An Open, Sustainable and Assertive Trade Policy' (18 February 2021) COM (2021) 66 final, <https://trade.ec.europa .eu/doclib/docs/2021/february/tradoc_159438.pdf> accessed 28 April 2021.

16 See supra $\mathrm{n} 7$ for the number of cases arising from the US restrictions of 2018. 
What are the possible solutions to this stalemate, supposing that a new more cooperative climate emerges after the change of the US administration in early 2021? There is hope since the GATT/WTO-based multilateral trading order is still considered by all G-2O members, though with differences as to their individual engagement, the fundamental valuable framework for regulating world trade. ${ }^{17}$ The mutual suspension in March 2021 of the countermeasures in place by the United States and the European Union in the Boeing-Airbus row is a good omen.

A review of the adequacy of existing substantive and procedural rules should be an objective of any 'revitalizing multilateralism in respect to trade' program in order to evaluate whether and how far these rules should be amended and updated also in light of new political and economic concerns in today's interconnected, digital world. Such a review could lead to granting some more leeway to the protection of national interests by individual countries in specific instances while protecting the foreign 'victims' of those restrictions. As an example, one could envisage enlarging the right to resort to the security exception also beyond the context of an international emergency amounting to an international conflict, such as is currently limited under Article XXI GATT. In such a case, however, immediate rebalancing countermeasures/safeguards by the parties affected should be allowed in the form of proportionate restrictions to the exports of the party resorting to the exception. Unilateral suspension of a previously accepted commitment must come at a price in a system based on reciprocity.

Efforts to reach agreement should precede unilateral measures - notably to ensure the supply of essential food products, pharmaceuticals, medical devices, and vaccines, thus avoiding unilateral restrictions, especially in connection with a pandemic.

In any case, recourse to unilateral instruments (and to any countermeasures) should remain subject to effective international collective verification and to prompt efficient ex-ante and ex-post controls and remedies. The same should be said for bilateral deals whenever they are not building blocks for multilateral cooperation promoting further liberalization, but instead undermine the respect of multilateral rules including the basic principle of non-discrimination beyond the limits of Article XXIV GATT.

17 As to the European Union, see the proposals on WTO reform annexed to the Commission's Communication referred to in supra $\mathrm{n} 15$. 
Based on the views expressed in current debates and in light of the above background, any suggestion aiming at revitalizing the operation of the WTO system should be focused in two directions. First, existing problems in the functioning of the organization should be addressed; then, secondly, new issues, both procedural and substantive should follow.

\subsection{Addressing the Current Shortcomings in the Operation of the WTO}

These shortcomings can be fixed by improving the WTO operating practice through enhanced engagement and cooperation by its members without the need to amend the existing rule-book or add new rules. These issues include those which are currently under negotiation at the WTO, both in multilateral negotiations (fishing) or in plurilateral format (environmental products - EPA, services - TISA). They also include enhancing the ability of the WTO to tackle issues such as cooperation in facing pandemics, climate change and the protection of the environment, supporting sustainable development through trade and achieving the UN goals in this respect. Addressing these objectives effectively requires improving the working methods of the WTO and the approach to consensus building and problem solving by the WTO members.

Issues concerning the current operation of the WTO are:

1. Devising more efficient management of the system and methods of negotiations (small committees, groups of experts, etc.).

2. Enhancing compliance with and surveillance of notification obligations, expanding their reach.

3. Transparency.

4. Cooperation with civil society, non-State stake holders.

5. Possible recourse to voting when allowed by current rules. ${ }^{18}$

6. Enhancing the support role of the Secretariat and its autonomy.

7. Reinvigorating the Trade Policy Review Mechanism (TPRM), possibly expanding its scope. Horizontal review of selected trade policies by groups of countries could be added to the current country-by-country exam of policies. This would enable comparing the level of commitments undertaken by different countries, review shortcomings of current disciplines, build awareness and consensus on the need to update the existing rule-book. majority of the General Council under art IX (2) of the WTO. 
8. Revising the DSS to improve its efficacity:

i. making the consultation pre-panel phase more robust with a view to prevent, conciliate, and resolve disputes at an early stage (i.e., through a facilitator's technical role for the Secretariat),

ii. streamlining and accelerating the panel process (notably as to support of the Secretariat, selection of panelists, and their commitment and availability),

iii. reinstating the Appellate Body by fixing any shared perceived shortcoming (Ambassador's Walker proposals of 2019 should be the basis ${ }^{19}$ ) in the settlement of disputes at the appellate stage, and

iv. improving the compliance stage by additional surveillance by the membership.

\subsection{Addressing 'New', Emerging Issues Concerning the Regulation of International Trade}

The first step is to devise the most appropriate negotiating format to achieve results (multilateral, plurilateral, building on regional agreements, establishing specialized groups) and to select the most pressing issues where broad consensus can be achieved.

Procedurally this implies:

1. Recourse to WTO-plus solutions that have been agreed in megaregionals and other agreements (i.e. as to State-owned-enterprises and subsidies or in respect of speedy resolution of disputes and recourse to rebalancing/countermeasures, such as in the Trade and Cooperation Agreement (TCA) between the European Union and the UK post-Brexit). ${ }^{20}$

2. Reflecting on the option to go beyond the single undertaking approach as to new 'independent' agreements.

3. Avoiding that consensus be used as a veto by any country to prevent the start of negotiations, including mini-rounds.

19 See WTO General Council, 'Agenda Item 4 - Informal Process on Matters Related to the Functioning of the Appellate Body - Report by the Facilitator, HE Dr David Walker (New Zealand)' (15 October 2019) JOB/GC/222.

20 The concept of a 'level playing field' introduced there, and the mechanisms devised to ensure its respect, could be introduced in WTO agreements. See Paola Mariani and Giorgio Sacerdoti, 'Trade in Goods and Level Playing Field' in Federico Fabbrini (ed), The Law \& Politics of Brexit. Volume 3: The Framework of New EU-UK Relationships (OUP 2021) (forthcoming). 
4. Reflecting on recourse to a 'plurilateral approach', both as a method of negotiation (between the parties most interested) and a secondbest solution for concluding new agreements. Discrimination in negotiations by those who participate against non-participants must be avoided. In any case, plurilaterals must be open to accession by all WTO members. On the other hand, irritation is mounting towards WTO members who do not engage and rely on their blocking powers to prevent others from proceeding together, especially once a critical mass of interested participants has been reached.

5. The issue of special and differential treatment (developing country status $)^{21}$ is on the table. Differentiating among obligations to be undertaken by WTO members in new agreements, especially as to timing of commitments (as it was done in the Trade Facilitation Agreement) may not be enough to address the problem. An à la carte approach, both as to countries and as to specific obligations might be more promising.

6. Environment and climate change measures, addressing the relationship between the Paris Agreement and WTO agreements and the challenge of border adjustment measures (carbon tax).

7. Labor, human rights (the role of women in trade), business social and corporate governance obligations (SMEs): how to incorporate non-trade concerns in the WTO inter-governmental framework. This approach is now a standard feature of the EU agreements, in FTAs (as in the one with Korea), ${ }^{22}$ as well as investment (the recent Comprehensive Agreement on Investments between the European Union and China) and other agreements (the EU-UK Trade and Cooperation Agreement).

21 The United States has suggested that participation of a country in the G-20, that is being a major economic and trading power, be considered incompatible with developing member status, Memorandum for the US Trade Representative, 'Reforming Developing-Country Status in the World Trade Organization' (26 July 2019) <www .federalregister.gov/documents/2019/o7/31/2019-16497/reforming-developing-country -status-in-the-worldtrade-organization $>$. See generally Weinian Hu, 'China as a WTO Developing Member, Is It a Problem?' (November 2019) CEPS Political Insight No 2019/16 $<$ www.ceps.eu/ceps-publications/china-as-a-wto-developing-member-is-it-a-problem/ \#: :text=The\%2odeveloping\%2omember\%2ostatus\%2oper,China\%2oparticipated\%2O in\%2oare\%2oconcerned.> both accessed 28 April 2021.

22 See 'Panel of Experts Confirms Republic of Korea is in Breach of Labour Commitments Under Our Trade Agreement' (25 January 2021) <https://trade.ec.europa.eu/doclib/press/ index.cfm?id=2238 $>$ accessed 28 April 2021. 
Tackling these issues at a global scale will be difficult. In my view this approach is however necessary in order to promote globalization with a human face and make progress towards a level playing field for enterprises based in different economies while increasing at the same time support for open markets within civil society.

\section{Biographical Note}

Giorgio Sacerdoti is emeritus professor of international law, Bocconi University, Milan, Italy; former chairman of the WTO Appellate Body. 